\title{
Small-Medium Enterprises Stickiness on the Traditional Accounting Systems
}

\author{
Jufri Darma ${ }^{1,}$, Taufik Hidayat ${ }^{1}$, Haryani Pratiwi Sitompul ${ }^{1}$, Dedy Husrizal Syah ${ }^{1}$, \\ Gaffar Hafiz Sagala ${ }^{1}$
}

\author{
${ }^{1}$ Universitas Negeri Medan \\ ${ }^{*}$ Corresponding author. Email: jufridarma@unimed.ac.id
}

\begin{abstract}
This study aims to identify the causes of the limited absorption of the accounting information system (AIS) in SMEs that are members of the UPPKS (Upaya Peningkatan Pendapatan Keluarga Sejahtera -in English: Business to Increase Prosperous Family Income) Program in Medan City. This research is necessary because, inpreliminary research observations, the researcher found that $81.30 \%$ of SMEs who are members of the UPPKS Medan City have not used AIS in accounting records. Eventhough in this digital era, the use of information technology is regular in every activity. The sample of this research is the SMEs that are members of the UPPKS in Medan City. UPPKS is a family empowerment program to maximize economic income through entrepreneurial activities. The program is organized by the Government of the Republic of Indonesia through the National Population and Family Planning Agency. The data collection in this study was using an electronic questionnaire collected using the snowball method. With simple random sampling, this study managed to collect 122 data. The entire data was then analyzed using descriptive statistics. The results showed that the SMEs that were members of the UPPKS in Medan City experienced Knowledge Stickiness. This condition hinders the performance of SMEs in utilizing AIS to achieve its competitive advantage. This study recommends UPPKS administrators to be able to manage SMEs' knowledge to be able to absorb knowledge from external parties and exploit it to produce measurable innovations. The innovation in question can generate increased economic benefits among SMEs.
\end{abstract}

Keywords: SMEs, Information System, Accounting, Knowledge Management

\section{INTRODUCTION}

Since 1993, the Government of Indonesia, through the National Family Planning Coordinating Board (in Bahasa-BKKBN), has organized a program called Business to Increase Prosperous Family Income (UPPKS) to increase economic growth by empowering familyproductivity[1].The UPPKS program assis tslowincome families to run a business by relying on family members as business actors and their workforce. With these efforts, households are expected to become entrepreneurs or SMEs to increase their economic productivity [2].

However, in this effort, some obstacles hinder the growth of these entrepreneurs in competing. Based on preliminary observations and interviews, $81.30 \%$ of SMEs who are members of the UPPKS still carry out manual financial records, and the rest $(12.70 \%)$ do information system-based recording. It is feared that this condition will result in a slowdown in decision-making and has implications for business entities' low performance $[3,4,5]$. From an accounting point of view, accounting information is a crucial source of business management information in formulating various decisions in solving all problems faced by businesses. The basis for decision making can be determined based on cost report data and financial reports by tracking cost drivers and profit drivers. Accounting information presents data on financial transactions of all activities in a business unit, whether in service, trading, or manufacturing businesses [6]. In this digital era, the management of accounting information has been transferred to an information technology system. Thus, the management and use of accounting information 
should be more efficient and valuable in generating strategic decision making.

The low absorption of accounting information systems at UPPKS in Medan City shows contradictions in business practices both theoretically and best practices of SMEs. The use of information technology today has become an integral part of a business entity [7]. Indeed, the level and type of Information Technology (IT) integration in business entities cannot be the same. There are alignment and contingency problems inIT investment $[3,4,7,8]$. Especially for SMEs, their dependence on IT is certainly not as significant as large companies' dependence on IT in achieving competitive advantage $[7,9]$. However, the use of IT inevitably provides efficiency benefits in business, especially in providing financial information. This efficiency will systemically reduce costs and produce valuable information that will, directly and indirectly, provide economic benefits for SMEs.

This study aims to identify the causes of the limited absorption of accounting information systems at SMEs that are members of the UPPKS in Medan City. Ahmad \& Al-Shbiel's research [3] reveals that the use of accounting information systems that impact business performance depends on the quality of knowledge management in SMEs. Various studies and literature have indicated that knowledge management is an integral part ofachievinganorganization'scompetitive advantage $[10,11,12]$. [13] and [14] reveal that the accounting information system is an essential instrument in the sustainability of knowledge management. However, this research believes that knowledge management is the cause of the absorption of an IT, including accounting information systems. This study uses the knowledge stickiness construct to identify the limitations of SMEs in absorbing accounting information systems. The knowledge stickiness construct has previously been used to review SMEs' competitive advantage in Indonesia [15.16]. Interestingly, this construct has never been used to identify SMEs' limitations in using accounting information systems, even though there have been many studies that associate the use of accounting information systems with knowledge management. In contrast, knowledge stickiness is an essential variable in identifying the stagnation of business entities in innovation.

\section{LITERATURE REVIEW}

In IT investment, besides the alignment issue, there is a stickiness issue that will affect company performance, including SMEs in innovation. If IT-alignment talks about the suitability of the technology invested with the company's needs, stickiness speaks of the company's difficulty changing from the old way of working to the new way of working. Knowledge stickiness describes the stagnation of an entity in making changes or absorbing new knowledge so that it has implications for inhibiting innovation in that entity.

The low acceptance of AIS in SMEs can still be viewed from an alignment perspective. Chang and Lee [17] have the preference that IT-alignment related to the use of AIS on SMEs is indeed influenced by the degree of a firm's information requirements. The company's needs are the factors that most determine how sophisticated the information system will be invested (Bolon, 1998). Thus, SMEs' reluctance to adopt AIS could occur because of the simplicity of accounting records that they need. [18] reveal that most SMEs feel that they run small businesses that can only meet daily needs. This condition makes them feel that traditional accounting records are more comfortable and practical. This condition causes the use of AIS in their accounting records, considered burdensome [19]. Because this results in SMEs having to cost time and energy to learn new skills [9]. Meanwhile, traditional recording alone is sufficient to help SME owners run their business. Moreover, some SMEs even feel that conventional accounting is more effective.

However, accounting records themselves are more than just informing the company's costs and the income it already has. More than that, accounting provides information about how revenue and expansion can be optimized to increase company profitabilityfromproduct innovation, production processes, and marketing [see:20]. Thus, the adoption of AIS cannot be viewed as merely generating financial data, but financial information that can spark innovation. The use of AIS can help SMEs find efficiency and effectiveness in managing their business [21]. It indicates that the stagnation of SMEs is not only in adopting AIS but also includes aspects of the use of information presented by the AIS. Likewise, SMEs' reluctance to use AIS has become a key indicator of the limitations of these SMEs. Moreover, this study reviews it with the construct of knowledge stickiness, which fundamentally explores the dynamics of SMEs' knowledge.

The concept of stickiness was first conceived by Von Hippel [22], who used the term to describe the costs of accessing and sharing information for innovation because knowledge is socially embedded in organizations and practices. The cost referred to here can be taking thought, energy, time, and money. According to Nonaka and Takeuchi [12], knowledge stickiness can be defined as the extent to which knowledge cannot be replaced from its source or original form. This form of knowledge is difficult to remove, transfer, and shape in a new business context. Knowledge Stickiness can be illustrated as the difficulty of adopting new knowledge, even within the organization's internal boundaries [12]. 


\section{RESEARCH METHOD}

This study uses a quantitative approach by survey methods. This study took a sample of UPPKS in Medan City using a questionnaire. We use an electronic questionnaire to collect data. This research instrument was adapted from Szulanski [23] related to knowledge stickiness. The survey is filled out by contacting the respondent via mobile phone. Enumerators carry out data collection to maintain data independence. The sampling technique used is simple random sampling. The data collected was then analyzed using descriptive statistics to review the patterns of knowledge stickiness experienced by UPPKS in Medan City.

\section{RESULTS AND DISCUSSION}

The demographic of the sample shows that 73of them are female. Furthermore, the sample is evenly distributed

Table 1. Demography of Sample

\begin{tabular}{|c|c|c|c|}
\hline Indicator & & $\mathrm{n}$ & $\%$ \\
\hline \multicolumn{4}{|l|}{ Gender } \\
\hline & Male & 49 & $40 \%$ \\
\hline & Female & 73 & $60 \%$ \\
\hline & & 122 & $100 \%$ \\
\hline \multicolumn{4}{|l|}{ Age } \\
\hline & $21-30$ & 26 & $21 \%$ \\
\hline & $31-40$ & 33 & $27 \%$ \\
\hline & $41-50$ & 48 & $39 \%$ \\
\hline & $>50$ & 15 & $12 \%$ \\
\hline & & 122 & $100 \%$ \\
\hline \multicolumn{4}{|l|}{ Type of Business } \\
\hline & Workshop & 14 & $11 \%$ \\
\hline & Draper & 8 & $7 \%$ \\
\hline & Grocery & 20 & $16 \%$ \\
\hline & $\begin{array}{l}\text { Creative Industry/ } \\
\text { Entertainment }\end{array}$ & 8 & $7 \%$ \\
\hline & Culinary & 54 & $44 \%$ \\
\hline & Tailor & 2 & $2 \%$ \\
\hline & Other & 16 & $13 \%$ \\
\hline & & 122 & $100 \%$ \\
\hline \multicolumn{4}{|l|}{ Age of Business } \\
\hline & $0-5$ & 67 & $55 \%$ \\
\hline & 6-10 & 31 & $25 \%$ \\
\hline & $11-15$ & 8 & $7 \%$ \\
\hline & $>15$ & 16 & $13 \%$ \\
\hline & & 122 & $100 \%$ \\
\hline \multirow{7}{*}{$\begin{array}{l}\text { Average Income } \\
\text { (monthly) }\end{array}$} & & & \\
\hline & $<2.500 .000$ & 26 & $21 \%$ \\
\hline & $2.500 .000-5.000 .000$ & 56 & $46 \%$ \\
\hline & $5.000 .001-7.500 .000$ & 13 & $11 \%$ \\
\hline & $\begin{array}{l}7.500 .001- \\
10.000 .000\end{array}$ & 12 & $10 \%$ \\
\hline & $>10.000 .000$ & 15 & $12 \%$ \\
\hline & & 122 & $100 \%$ \\
\hline
\end{tabular}

at each age level. Retailer, service, and manufacture businesses were representing the sample category in business type. Most of the samples have 0-5 years and 610 years of business experience. Then, the sample is dominated by SMEs with turnover below Rp. 5,000,000 (US\$ 338), per year. This figure shows that the SMEs being sampled are small-sized SMEs.
The data collected from the respondents above are then tabulated and analyzed by their descriptive statistics.

This study identifies knowledge stickiness according to four dimensions: interconnected, sensory knowledge, coded knowledge, and theoretical knowledge. The four dimensions' value has been converted into a percent (\%) with a maximum value of $100 \%$. The higher the number of each aspect, the smaller the respondent's knowledge stickiness (SMEs), and vice versa. The percentage figure is also confirmed by the standard deviation value to determine the data's level of variation. Each dimension is reviewed from the respondent's perception based on thirteen possible sources of knowledge: buyers, suppliers, competitors, consultants, government offices, industry associations, religions, universities, exhibitions, print media, electronic media, radio, and the internet. The presentation results and the mean presented are a summary of the overall perceptions grouped into the dimensions of knowledge stickiness used. The results of descriptive statistics can be reviewed in Table 2 below.

The interconnected dimension refers to how often SMEs get specific knowledge about improving the accounting recording system from external parties. Interconnected explains SMEs' ability to link the information available from external parties with the needs of these SMEs to update how they work. In this dimension, the response shows that the respondent has $46.07 \%(<50 \%)$ interconnected capacity. This figure indicates that the respondents do not have sufficient

Table 2. Demography of Sample

\begin{tabular}{|c|l|l|c|r|}
\hline No & Variable & $\%$ & Avg & St.Dev. \\
\hline 1 & Interconnected & $46,07 \%$ & 2,30 & 0,84 \\
\hline 2 & Sensory Knowledge & $42,41 \%$ & 2,12 & 0,82 \\
\hline 3 & Coded Knowledge & $45,70 \%$ & 2,28 & 0,91 \\
\hline 4 & Theoritical Knowledge & $46,88 \%$ & 2,34 & 0,94 \\
\hline
\end{tabular}

interconnected capacity. SMEs have not been able to connect the availability of information from external parties with their needs to produce innovations in technology-oriented accounting records.

Then, the sensory knowledge dimension explains how easily SMEs can practice the knowledge they receive from external parties. After linking external knowledge with their initial knowledge, SMEs need the knowledge to put it into practice. The limitations of SMEs in practicing new knowledge in an existing process indicate the occurrence of knowledge stickiness. The number of dimensions of sensory knowledge owned by respondents is $42.41 \%(<50 \%)$. This figure is in line with the figure from the interconnected dimension. SMEs will find it challenging to implement new knowledge in existing practices if SMEs have difficulty connecting external knowledge with their internal knowledge. The 
low number of sensory knowledges further strengthens that SMEs experience knowledge stickiness.

The Coded Knowledge dimension shows that companies can quickly write down the new knowledge they get in instruction manuals, guides, and procedures. Information obtained from external companies must be able to translate and adapt to the company's interests and needs and then write down these adjustments so that they can be implemented technically by all company members. Like interconnected and sensory knowledge, respondents show a number that is not good for coded knowledge, namely $45.70 \%(<50 \%)$. This figure shows that SMEs have difficulty documenting their newly acquired knowledge into new methods of improving business performance. In the context of this research, SMEs find it challenging to write AIS-based recording procedures that allow financial staff to study and use them. This difficulty may occur not only because of technical problems but the limitations of SMEs in associating the needs of AIS in producing company efficiency and effectiveness, which have implications for business profitability.

Furthermore, theoretical knowledge explains how easily SMEs can disclose what and how they receive from external parties. Mastery of knowledge is indicated when a person or organization can define that knowledge's content to other parties in a comprehensive manner. SMEs can be said to be able to master new knowledge if it can connect it with old knowledge, implement it, design the procedure manually, and explain all the articulations in one complete framework. In the theoretical knowledge dimension, respondents still show the same trend: $46.88 \%(<50 \%)$. This figure indicates that SMEs experience knowledge stickiness so that it is difficult for them to adopt and exploit AIS in their business operations.

\section{CONCLUSION}

This study aims to identify the causes of the limited absorption of accounting information systems at SMEs that are members of the UPPKS in Medan City. Most of the SMEs that are members of the UPPKS still keep traditional records. The stagnation of UPPKS in innovating their businesses is thought to have occurred because UPPKS have relatively low literacy and inclusion in using AIS. This study's results have confirmed that the limitations of inclusion and literacy occur because SMEs experience knowledge stickiness. The four dimensions analyzed, interconnected, sensory knowledge, coded knowledge, and theoretical knowledge, show relatively low numbers. This figure consistently indicates that SMEs that are members of the UPPKS in Medan City experience knowledge stickiness. Knowledge stickiness inhibits the absorption of AIS in these SMEs. SMEs find it difficult to accept new knowledge, associate it with old knowledge, implement it in current business processes, develop it into new operating procedures, and explain it back to others. These conditions certainly hinder the absorption of IT for corporate innovation. SMEs have difficulty adopting new knowledge because they have not been able to construct new business models and project benefits on all aspects of the business from external parties' new experience. SMEs need to develop knowledge capacity so that they can manage their activities more dynamically.

Theoretically, this study will provide additional insights regarding the barriers to using AIS for SMEs that are members of the UPPKS from a knowledge management point of view. This study also confirms the theoretical perspective of the importance of knowledge management in entrepreneurial groups, such as the UPPKS, to share insights on an ongoing basis in using AIS. SMEs need an ecosystem that generates pressure for SMEs themselves to develop their knowledge capacity. A dynamic entrepreneurial ecosystem will produce a culture to improve the internal knowledge capacity of every entrepreneur sustainably.

In practice, this research contributes to providing strategic recommendations for UPPKS managers to develop the competitiveness of SMEs through their knowledge capacity. UPPKS managers can assist SMEs to associate new knowledge with existing SMEs practices gradually. Especially in using AIS, UPPKS managers can help SMEs practice them in running business processes and train SMEs to optimize the use of accounting information available in AIS to innovate SMEs' business processes. So that, in turn, SMEs will feel the benefits through increased financial benefits.

This research contributes to exploring the root causes of the inhibition of knowledge absorption regarding the use of AIS for SMEs so that UPPKS administrators can control these obstacles with the right target. This study provides a bridge for further researchers to explore strategies for optimizing AIS use in SMEs. Researchers can then explore strategies to increase AIS inclusion for SMEs concerning stimulating business innovation in SMEs.

\section{ACKNOWLEDGMENTS}

This Study was funded by Universitas Negeri Medan (UNIMED) Research Grant.

\section{REFERENCES}

[1] Badan Koordinasi Keluarga Berencana Nasional, Pedoman Pengelolaan Program Pemberdayaan Ekonomi Keluarga bagi Pendamping Kelompok UPPKS, Jakarta, 2010

[2] Hikmat, H., Strategi Pemberdayaan Masyarakat, Bandung: Humaniora Utama Press, 2010 
[3] Ahmad, M. A., \& Al-Shbiel, S. O., The effect of accounting information system on organizational performance in Jordanian industrial SMEs: The mediating role of knowledge management. International Journal of Business and Social Science, 10 (3), 2019, 99-104.

[4] Harash, E., The Role of Environmental Uncertainty in the Link between Accounting Information System and Performance Small and Medium Enterprises in Iraq. Global Journal of Management and Business Research, 15(2), 2015, 26-32.

[5] Ismail, N. A., Factors influencing AIS effectiveness among manufacturing SMEs: Evidence from Malaysia. The Electronic Journal of Information Systems in Developing Countries, 38(1), 2009, 119.

[6] Fitriyah, H., Analisis Faktor-faktor yang Mempengaruhi Penggunaan Informasi Akuntansi pada Usaha Menengah di Kabupaten Sidoarjo. Master Thesis. Surabaya: Universitas Airlangga, 2006

[7] Ismail, N. A., \& King, M., Factors influencing the alignment of accounting information systems in small and medium sized Malaysian manufacturing firms. Journal of Information Systems and Small Business, 1(1-2), 2014, 1-20.

[8] Grande, E. U., Estébanez, R. P., \& Colomina, C. M., The impact of Accounting Information Systems (AIS) on performance measures: empirical evidence in Spanish SMEs. The international journal of digital accounting research, 11(1), 2011, 25-43.

[9] Putra, Y. M., Analysis of Factors Affecting the Interests of SMEs Using Accounting Applications. In: Journal of Economics and Business, Vol. 2, No.3, 2019, 818-826.

[10] Wang, D. H. M., \& Huynh, Q. L., Mediating role of knowledge management in effect of management accounting practices on firm performance. Journal of Knowledge Management, Economics and Information Technology, 3(3), 2013, 1-25.

[11] Lakshman, C., Organizational knowledge leadership: A grounded theory approach. Leadership \& Organization Development Journal, 2007.

[12] Nonaka, I., \& Takeuchi, H., The knowledgecreating company: how Japanese companies create the dynamics of innovation. Oxford: Oxford university press, 1995

[13] Jalilv and, M. R., Pool, J. K., Khodadadi, M., \& Sharifi, M., Information technology competency and knowledge management in the hospitality industry service supply chain. Tourism Review, 2019 ,

[14] Sori, Z. M., Accounting information systems (AIS) and knowledge management: a case study. American Journal of scientific research, 4(4), 2009, $36-44$.

[15] Indarti, N., The Effect of Knowledge Stickiness and Interaction on Absorptive Capacity Evidence from furniture and software SMEs in Indonesia. University of Groningen, Groningen, The Netherlands, 2010.

[16] Indarti, N., \& Langenberg, M., Factors affecting busines success among SMEs: Empirical evidences from Indonesia. Proceedings of the Second BiAnnual European Summer University 2004, University of Twente, Enschede, The Netherlands. 2004, 1-14.

[17] Chang, C.H. and Jevons Lee, C.W., 'Information acquisition as business strategy', Southern Economic Journal, vol. 58, no. 3, 1992, pp. 750-761.

[18] Rahmawati, T., \& Puspasari, O. R., Implementasi sak etap dan kualitas laporan keuangan UMKM terkait akses modal perbankan. Kajian Akuntansi, 1(1), 2017, 49-62.

[19] Putri, A. H. K., Pengaruh Faktor Latar Belakang Pendidikan Terhadap Kualitas Laporan Keuangan Melalui Pengetahuan AKuntansi Sebagai Variabel Intervening. Ihtiyath: Jurnal Manajemen Keuangan Syariah, 1(2), 2017, 32-52.

[20] Horngren, C. T., Datar, S. M., \& Rajan, M. V., Cost accounting: A managerial emphasis, 2015

[21] Lestiawan, H., \& Mahmud., Purwarupa Pembelajaran Mandiri Sistem Aplikasi Akuntansi UMKM Berbasis Web Dalam Pemberdayaan Usaha Masyarakat Jawa Tengah. Prosiding SNATIF, 2014, 445-452.

[22] Von Hippel, E., Sticky information and the locus of problem solving: implications for innovation. Management Science, 1994, 429-439.

[23] Szulanski, G., Exploring internal stickiness: Impediments to the transfer of best practice within the firm. Strategic management journal, 17 (S2), 1996, 27-4. 